\title{
Soil Biological Health, Tuber Yield and Starch Content under Permanent Manurial Experiment on Cassava
}

\author{
S. Suganya* \\ Assistant Professor (SS\&AC), TNAU Information and Training Centre, Chennai, India \\ *Corresponding author
}

\section{Keywords}

Permanent Manurial Experiment (PME), Tuber yield, Starch content, Cassava, Soil microbial properties

\section{Article Info}

Accepted:

15 April 2020

Available Online:

10 May 2020

\section{A B S T R A C T}

Improving and maintaining soil quality for enhancing and sustaining agricultural production is of utmost importance for India's food and nutritional security. Permanent Manurial Experiments (PMW) are ideal sites for studying management induced variability in crop production and soil health. The biological activity of a soil is the function of number of organisms present in soil and their physiological efficiency. Soil microbial diversity is one of the most important microbial parameters in soil. Cassava is grown throughout the tropics, where it is the fourth most important staple food crop in terms of Kcal consumed per day. Cassava grows reasonably well with little or no fertilizer inputs, the crop does respond well to fertilizer applications in highly infertile soils. In some areas cassava has been cultivated continuously with improper fertilizer management. These factors have caused the soil's productivity to steadily decline, resulting in a decrease in cassava growth and yield. Another reason for stagnating yields may be the decline in soil productivity as a result of continuous cassava production without adequate fertilization. Hence, Permanent Manurial Experiment (PME) on cassava variety YTP 1 has been conducted for three years during 2014-2017at Tapioca and Castor Research Station, Yethapur, Salem district, Tamil Nadu with four treatments viz., control, organic manuring, inorganic fertilization and integrated nutrient management to study the effects on the yield and quality of cassava and the consequent changes in the biological properties of the soil under continuous cropping with and manuring. Among the treatments, Integrated Nutrient Management (INM) recorded higher plant height $(237 \mathrm{~cm})$, stem girth $(13 \mathrm{~cm})$, number of tubers (13), tuber length $(41.6 \mathrm{~cm})$ and tuber girth $(32.2 \mathrm{~cm})$ followed by inorganics and organics. Control recorded lesser plant height $(191 \mathrm{~cm})$, stem girth $(7.6 \mathrm{~cm})$, number of tubers $(8.0)$, tuber length $(19.4 \mathrm{~cm})$ and tuber girth $(11.0 \mathrm{~cm})$. The maximum tuber yield $\left(41.50 \mathrm{tha}^{-1}\right)$ and starch content $(26.50 \%)$ was recorded by the application of INM. Higher microbial population of bacteria, fungi and actinomycetes was recorded under organics (65.87, 26.54 and 9.98 respectively) followed by Integrated Nutrient Management (64.38, 25.87 and 9.47 respectively). Therefore, adoption of integrated plant nutrient supply and management strategies for enhancing soil quality, input use efficiency and crop productivity is extremely important for food and nutritional security in Indian agriculture. 


\section{Introduction}

Improving and maintaining soil quality for enhancing and sustaining agricultural production is of utmost importance for India's food and nutritional security. Permanent Manurial Experiments (PMW) are ideal sites for studying management induced variability in crop production and soil health (Mali et al., 2015). PME play an important role in understanding the complex interactions involving soils, climate and management practices and their effects on crop productivity. With globalization, Indian agriculture is passing through a critical phase. It is confounded with increasing crop production, sustainability and long-term environmental quality issues. These challenges can be sought out by the long-term experiments which are valuable repositories of information regarding the sustainability of intensive agriculture.

SOIL is known as the "Soul Of Infinite Life", continued maintenance of good soil health is vital to agricultural production. The soil health is continuously deteriorating due to imbalanced fertilizer use coupled with low use of organic manures and intensive system (Singh, 2010). The soils are not being adequately replenished even for the macronutrients, let alone the secondary and micronutrients. The improper nutrient management has, therefore, led to emergence of multi-nutrient deficiencies. Gap between nutrients required by the crops and amounts expected to be made available from soil nutrient supplies has to be bridged through external nutrient application. This can be done through a number of organic, microbial and mineral sources, in an integrated manner.

The PME serves as an important tool to understand the changes in soil properties due to intensive cropping and continuous fertilization. The importance of fertilization and manuring of our land is increasing day by day and farmers are supposed to use these inputs intensively for sustained crop production. Practices of intensive fertilization and manuring undoubtedly bring some changes in the physical and chemical properties of soil as well as biological properties. Cassava is usually grown by poor farmers in the tropics with a minimum of inputs. Continuous production under these conditions can lead to soil nutrient depletion.

Long term experiments provide the best possible means of studying changes in soil properties, nutrient dynamics and processes and identifying emerging trends in nutrient imbalances and deficiencies and to formulate the future strategies for maintaining soil health. In view of growing notion that "certain soil processes are long term in nature and must be studied as such". In view of growing importance of long-term experiments for addressing current and future agricultural and environmental issues Dawe et al., (2000), Powlson et al., (1998), Swarup (2001) made extensive efforts to review and document available data on yield trend analysis, soil properties and key sustainable indicators such as organic carbon which cannot be measured from short-term studies and identified regional fertility constraints and opportunities to increase agricultural productivity through integrated plant nutrient supply. These experiments have provided very valuable data relevant for farmers, scientists and policy makers.

Sustainability of agriculture in the country like India is of prime importance. The result on long term fertilizer experiments proved that sustainability is impossible without the use of fertilizer. However, indiscriminate use of fertilizer without scientific basis may lead to harmful effect on soil and crops. Therefore, it is necessary to have a constant watch on soil properties. Long-term experiments in 
India have generated large and valuable information's which are used for sustainability of the intensive agriculture. Changes in soil fertility, as a result of imbalanced fertilizer use and faulty management practices takes few years to appear disorder in soil but regresses several years to bounce back the same condition. The change in climate also has effect on productivity and soil quality.

The biological activity of a soil is the function of number of organisms present in soil and their physiological efficiency. All biological reactions in soil are catalyzed by enzymes. Soil enzyme activities are believed to indicate the extent of specific processes in soil and act as indicators of soil fertility. Soil organisms such as bacteria, fungi and actinomycetes are involved in different biochemical processes which occur in soils, including organic matter decomposition, humus formation and nutrient transformation and cycling and they play a vital role in maintaining soil productivity (Lin et al., 2004 and Smith and Paul, 1990). Soil microbial diversity is one of the most important microbial parameters in soil (Mali et al., 2015).

Hence, to study the effects of continuous cropping and manuring on the growth and yield of cassava a permanent manurial experiment was conducted in cassava. Cassava is grown throughout the tropics, where it is the fourth most important staple food crop in terms of Kcal consumed per day. There is no doubt that cassava is usually grown on the least fertilizer soils, and generally without fertilization. It is a typical small farmer crop that has the ability to produce reasonably well on poor soils with limited inputs, where most other crops would fail completely. Being a highly productive crop, cassava can extract rather large amounts of nutrients from the soil, but on the basis per ton of dry matter produced, this nutrient extraction tends to be lower than that of most crops, except for potassium. While cassava grows reasonably well with little or no fertilizer inputs, the crop does respond well to fertilizer applications in highly infertile soils. However, the fertilizer requirements were generally determined from short-term fertilizer trials, conducted in the same place for only one cropping season. Little information is available on the long-term effect of continuous cassava cultivation.

Most cassava is grown on coarse textured soils, with sandy clay loam and sandy loam textures and having low fertility. These soils have rather unfavorable physical and chemical properties, having a very light texture, low levels of organic matter, low contents of available nutrients. In some areas cassava has been cultivated continuously with improper fertilizer management. These factors have caused the soil's productivity to steadily decline, resulting in a decrease in cassava growth and yield. It has long been recognized that certain nutrient elements are essential for plant growth and normal development. It has also been known that the lack of one or more of the essential elements leads to abnormalities of one sort or another. Lack of one or another of the essential elements in available form in the soil solution may lead to reduced growth, lower yields and inferior quality products. Another reason for stagnating yields may be the decline in soil productivity as a result of continuous cassava production without adequate fertilization and measures to control erosion (Howeler, 1991 and Kabeerathumma et al., 1990).

It is therefore, important to determine the long-term effect of cassava cultivation on soil fertility and crop productivity.

Hence, Permanent Manurial Experiment (PME) has been conducted for three years during 2014-2017 to study the effects on the 
yield and quality of cassava and the consequent changes in the biological properties of the soil under continuous cropping with and manuring.

\section{Materials and Methods}

A permanent long-term field experiment on cassava variety YTP 1 was conducted during 2014-17 at Tapioca and Castor Research Station, Yethapur, Salem district, Tamil Naduwith four treatments in larger plot size (9 $\mathrm{m} \times 28 \mathrm{~m}$ ) of 6.3 cents per treatment. The four treatments were laid out in Non-replicated design and the treatment details are as follows.

\section{Treatment details:}

$\mathrm{T}_{1}$ : Control

$\mathrm{T}_{2}$ : Organic manuring (FYM @ $25 \mathrm{tha}^{-1}$ )

$\mathrm{T}_{3}$ : Inorganic fertilization $(\mathrm{N}, \mathrm{P}$ and $\mathrm{K}$ recommendation based on STCR)

$\mathrm{T}_{4}$ : Integrated Nutrient Management (INM) $(\mathrm{N}, \mathrm{P}$ and $\mathrm{K}$ recommendation based on STCR-IPNS along with FYM @ $25 \mathrm{t} \mathrm{ha}^{-1}+$ and Azophos @ $2 \mathrm{~kg} \mathrm{ha}^{-1}$ )

The soil of the experimental field is red noncalcareous soil, sandy loam in texture (Typic Rhodustalf). Bulk density and particle density of the soil is 1.25 and $1.98 \mathrm{~g} \mathrm{cc}^{-1}$ respectively. Percent pore space of the soil is 18.2. The experimental soil had $\mathrm{pH} 7.5$, EC $0.21 \mathrm{dS} \mathrm{m}^{-1}$, Organic carbon $0.32 \%$, available nitrogen, phosphorus and potassium were $215 \mathrm{~kg} \mathrm{ha}^{-1}$, $4.8 \mathrm{~kg} \mathrm{ha}^{-1}$ and $347 \mathrm{~kg} \mathrm{ha}^{-1}$ respectively. Soil microbial load - total bacteria is $52.33 \times 10^{6}$ $\mathrm{CFU} / \mathrm{g}$ of soil, total fungi is $23.45 \times 10^{4}$ $\mathrm{CFU} / \mathrm{g}$ of soil and total actinomycetes is 8.50 $x 10^{6} \mathrm{CFU} / \mathrm{g}$ of soil. Nutrient content of the manures was analysed. Green manure (sunnhemp) contains 2.3:0.5:1.8\% NPK, poultry manure contains $2.15: 2.0: 2.8 \%$ NPK and farm yard manure contains $0.5: 0.2: 0.5 \%$ NPK. Fertilizers were applied as per the technical programme. In order to assess the effect of PME on cassava growth, yield and starch content, observations on plant growth parameters (plant height and stem girth), yield attributes (No. of tubers per plant, tuber length, tuber girth), tuber yield and starch content were recorded. In order to assess the biological properties, soil samples were collected and the total number of bacteria, fungi and actinomycetes were determined as colony forming units (CFU) on agar plates by dilution plate methods using respective media for each group as described by Dhingra and Sinclair (1993).

The details of analytical methods employed in the soil analysis were given in the table 1 .

\section{Results and Discussion}

The influence of different treatments on cassava plant growth, yield attributes, yield and starch content is given in Table 2 and 3. Among the treatments, Integrated Nutrient Management (INM) recorded higher plant height $(237 \mathrm{~cm})$, stem girth $(13 \mathrm{~cm})$, number of tubers (13), tuber length $(41.6 \mathrm{~cm})$ and tuber girth $(32.2 \mathrm{~cm})$ followed by inorganics and organics. Control recorded lesser plant height $(191 \mathrm{~cm})$, stem girth $(7.6 \mathrm{~cm})$, number of tubers (8.0), tuber length $(19.4 \mathrm{~cm})$ and tuber girth $(11.0 \mathrm{~cm})$.

Significant increase in tuber yield due to integrated nutrient management practice was observed. The maximum tuber yield $(41.50 \mathrm{t}$ $\mathrm{ha}^{-1}$ ) and starch content (26.50\%) was recorded by the application of INM. Over three years, control plot recorded a negative change in tuber yield to the tune of -1.48 tonnes whereas organics recorded a positive change in tuber yield to the tune of 11.06 tonnes and INM sustains the tuber yield with a positive change in tuber yield to the tune of 0.16 tonnes. 
The increase in grain yield with integrated nutrient management is mainly due to beneficial effect of combined use of organic manure and fertilizers as nutrient availability increased through enhanced microbial activity, conversion from unavailable to available forms and also due to improved physical, chemical and biological conditions. Cassava farmers apply farm yard manure either alone (organics)or in combination with chemical fertilizers (INM), to maintain or improve soil fertility. Application of manures may contribute to improving the soil's physical conditions and are an important source of $\mathrm{Ca}, \mathrm{Mg}, \mathrm{S}$ and micronutrients, they contain only low and highly variable amounts of $\mathrm{N}, \mathrm{P}$ and $\mathrm{K}$. This has corroboration with findings of George et al., (2001) and Susan John et al., (1998).

The availability of micronutrients viz., $\mathrm{Cu}$ and $\mathrm{Zn}$ reduced appreciably due to continuous cultivation. However, balanced application of $\mathrm{N}, \mathrm{P}$ and $\mathrm{K} @ 100 \mathrm{~kg} \mathrm{ha}^{-1}$ each along with $12.5 \mathrm{t} \mathrm{ha}^{-1}$ FYM was found the best combination of nutrients in terms of maintaining adequate nutrient balance in the soil (Susan John, 2005). Susan John (2005) reported from a long term manurial trial conducted during 1977- 1990 that balanced application of N, P and K @100:50:100 kg $\mathrm{ha}^{-1}$ along with FYM @ $12.5 \mathrm{t} \mathrm{ha}^{-1}$ is beneficial in increasing yield. The pooled data of the 14 years on yield was highest for the above treatment with a yield of $28.18 \mathrm{t} \mathrm{ha}^{-1}$ whereas the absolute control recorded an yield of $4.41 \mathrm{t} \mathrm{ha}^{-1}$ only. It was also seen from continuous application of fertilizers and manures that $3 / 4^{\text {th }}$ recommended dose of $\mathrm{N}, \mathrm{P}$ and K (NPK@ 75:37.5:75 kg ha ${ }^{-1}$ ) along with FYM @ 12.5 tha $^{-1}$ can produce an yield $\left(23.70 \mathrm{t} \mathrm{ha}^{-1}\right)$ on par with the recommended dose of NPK @ 100:50:10 kg ha ${ }^{-1}$ along with FYM@12.5 tha ${ }^{-1}\left(25.42 \mathrm{tha}^{-1}\right)$.
In control treatment, continuous cassava cultivation on the same land may lead to nutrient depletion due to nutrient absorption by the crop and nutrient removal in the harvested products (Hagens and Sittibusaya, 1990). In general, the nutrient removal in either the roots or the whole plant per tonne of fresh roots is higher at high than at low yield levels because at higher levels of fertility, plants have higher nutrient concentrations resulting in higher yields (Chan, 1980).

Higher microbial population of bacteria, fungi and actinomycetes was recorded under organics (65.87, 26.54 and 9.98 respectively) followed by Integrated Nutrient Management (64.38, 25.87 and 9.47 respectively) (Table 4). The microbial population was significantly higher under INM. Integrated Nutrient Management proved better than fertilizers alone in helping the multiplication of microbial population. Relatively higher rate of multiplication of microbe was associated with Farm Yard Manure, which might be due to the ready source of carbon from FYM that acts as substrate for stimulation of bacterial growth. Bharadwaj and Omanwar (1992) and Malewar et al., (1999) reported that a higher number of bacteria were found in integrated use of organics and fertilizers. Increased fungal population can be ascribed to the decomposed food material available form organic sources. The findings are in conformity with the results of Malewar et al., (1999) and Vineela et al., (2008). Increased production of actinomycete can be attributed to decomposition of organic matter added to the soil. It indicates that judicious use of organic manures and fertilizers is essential to maintain soil flora for sustainable agriculture. Vineela et al., (2008) reported that use of INM was beneficial in increasing microbial population over NPK in rainfed production systems in the semi-arid tropics of India. 
Table.1 Details of analytical methods employed in the soil analysis

\begin{tabular}{|c|c|c|c|}
\hline S. No & Parameters & Methods & References \\
\hline \multicolumn{4}{|c|}{ a) Physical properties } \\
\hline 1. & $\begin{array}{l}\text { Particle size } \\
\text { analysis }\end{array}$ & $\begin{array}{l}\text { International pipette } \\
\text { method }\end{array}$ & Piper (1966) \\
\hline 2. & Bulk density & Core method & $\begin{array}{l}\text { Gupta and } \\
\text { Dakshinamoorthy (1981) }\end{array}$ \\
\hline 3. & Particle density & Core method & $\begin{array}{l}\text { Gupta and } \\
\text { Dakshinamoorthy (1981) }\end{array}$ \\
\hline 4. & Porosity & Core method & $\begin{array}{l}\text { Gupta and } \\
\text { Dakshinamoorthy (1981) }\end{array}$ \\
\hline \multicolumn{4}{|c|}{ b) Physico - chemical properties } \\
\hline 1. & Soil reaction & $\begin{array}{l}\text { Soil water suspension } \\
(1: 2.5)\end{array}$ & Jackson (1973) \\
\hline 2. & $\mathrm{EC}$ & $\begin{array}{l}\text { Soil water suspension } \\
(1: 2.5)\end{array}$ & Jackson (1973) \\
\hline \multicolumn{4}{|c|}{ c) Chemical properties } \\
\hline 1. & Organic carbon & $\begin{array}{l}\text { Chromic acid wet } \\
\text { digestion }\end{array}$ & Walkley and Black (1934) \\
\hline 2. & $\mathrm{KMnO}_{4}-\mathrm{N}$ & Alkaline permanganate & Subbiah and Asija (1956) \\
\hline 3. & Olsen - P & $\begin{array}{l}\text { 0.5 M sodium bicarbonate } \\
(\mathrm{pH} 8.5)\end{array}$ & Olsen et al., (1954) \\
\hline 4. & $\mathrm{NH}_{4} \mathrm{OAc}-\mathrm{K}$ & $\begin{array}{l}\text { Neutral normal } \\
\text { ammonium acetate }\end{array}$ & $\begin{array}{l}\text { Stanford and English } \\
\text { (1949) }\end{array}$ \\
\hline d) & \multicolumn{3}{|c|}{ Biological properties } \\
\hline 1. & $\begin{array}{l}\text { Total number of } \\
\text { bacteria, fungi } \\
\text { and } \\
\text { actinomycetes }\end{array}$ & Dilution plate methods & $\begin{array}{l}\text { Dhingra and Sinclair } \\
\text { (1993) }\end{array}$ \\
\hline
\end{tabular}

Table.2 Plant growth and yield attributes as influenced by different treatments under PME in cassava

\begin{tabular}{|l|l|c|c|c|c|c|}
\hline $\begin{array}{r}\text { Trt. } \\
\text { No. }\end{array}$ & \multicolumn{1}{|c|}{ Treatments } & $\begin{array}{c}\text { Plant } \\
\text { height }(\mathbf{m})\end{array}$ & $\begin{array}{c}\text { Stem } \\
\text { girth }(\mathbf{c m})\end{array}$ & $\begin{array}{c}\text { No. of } \\
\text { Tubers } \\
\text { per plant }\end{array}$ & $\begin{array}{c}\text { Tuber } \\
\text { length } \\
\text { (cm) }\end{array}$ & $\begin{array}{c}\text { Tuber } \\
\text { girth }(\mathbf{c m})\end{array}$ \\
\hline T1 & Control & 191 & 7.6 & 8.0 & 19.4 & 11.0 \\
\hline T2 & Organic manuring & 223 & 10.4 & 10.0 & 26.9 & 20.2 \\
\hline T3 & $\begin{array}{l}\text { Inorganic } \\
\text { fertilization }\end{array}$ & 230 & 11.0 & 11.0 & 32.4 & 27.8 \\
\hline T4 & $\begin{array}{l}\text { Integrated Nutrient } \\
\text { Management }\end{array}$ & 237 & 13.0 & 13.0 & 41.6 & 32.2 \\
\hline
\end{tabular}


Table.3 Tuber yield and starch content as influenced by different treatments under PME in cassava

\begin{tabular}{|c|c|c|c|c|c|c|c|}
\hline \multirow[t]{2}{*}{$\begin{array}{l}\text { Trt. } \\
\text { No. }\end{array}$} & \multirow[t]{2}{*}{ Treatments } & \multicolumn{3}{|c|}{$\begin{array}{c}\text { Tuber yield } \\
\left(\mathbf{t ~ h a}^{-1}\right)\end{array}$} & \multicolumn{3}{|c|}{ Starch $(\%)$} \\
\hline & & $\begin{array}{c}\text { Mean } \\
(2014-16)\end{array}$ & $\begin{array}{c}\text { Current } \\
\text { year } \\
(2016-17)\end{array}$ & $\begin{array}{c}\text { Change } \\
\pm(\text { Value } \\
\text { or } \%)\end{array}$ & $\begin{array}{c}\text { Mean } \\
(2014-16)\end{array}$ & $\begin{array}{c}\text { Current } \\
\text { year } \\
(2016-17)\end{array}$ & $\begin{array}{c}\text { Change } \\
\pm(\text { Value } \\
\text { or } \%)\end{array}$ \\
\hline $\mathbf{T}_{1}$ & Control & 14.98 & 13.50 & -1.48 & 13.43 & 13.00 & -0.43 \\
\hline $\mathbf{T}_{2}$ & $\begin{array}{l}\text { Organic } \\
\text { manuring }\end{array}$ & 25.80 & 36.80 & 11.01 & 22.82 & 25.5 & 2.69 \\
\hline $\mathbf{T}_{\mathbf{3}}$ & $\begin{array}{l}\text { Inorganic } \\
\text { fertilization }\end{array}$ & 37.88 & 38.25 & 0.37 & 24.28 & 24.5 & 0.22 \\
\hline $\mathbf{T}_{4}$ & $\begin{array}{l}\text { Integrated } \\
\text { Nutrient } \\
\text { Management }\end{array}$ & 41.34 & 41.50 & 0.16 & 25.56 & 26.50 & 0.94 \\
\hline
\end{tabular}

Table.4 Soil microbial population as influenced by different treatments under PME in cassava during 2016-2017

\begin{tabular}{|l|l|c|c|c|}
\hline $\begin{array}{l}\text { Trt. } \\
\text { No. }\end{array}$ & Treatments & $\begin{array}{c}\text { Total Bacteria } \\
(\mathbf{x} \mathbf{1 0} \text { CFU/ } \\
\text { of soil })\end{array}$ & $\begin{array}{c}\text { Total Fungi }(\mathbf{x} \\
\mathbf{1 0}^{\mathbf{4}} \text { CFU/ } \\
\text { soil) }\end{array}$ & $\begin{array}{c}\text { Total } \\
\text { Actinomycetes } \\
\text { (x 10 } \mathbf{3} \text { CFU/ } \\
\text { of soil) }\end{array}$ \\
\hline T1 & Control & 40.31 & 19.87 & 8.10 \\
\hline T2 & Organic manuring & 65.87 & 26.54 & 9.98 \\
\hline T3 & Inorganic fertilization & 45.14 & 21.04 & 8.12 \\
\hline T4 & Integrated Nutrient Management & 64.38 & 25.87 & 9.47 \\
\hline & Mean & $\mathbf{5 3 . 9 3}$ & $\mathbf{2 3 . 3 3}$ & $\mathbf{8 . 9 2}$ \\
\hline
\end{tabular}

Continuous use of only fertilizers alone recorded lower bacterial count as compared to the integrated use of organics and fertilizers indicating the importance of INM in improving soil biological health. Increase in bacterial population could be the result of enhancement of SOM in soil (Mali et al., 2015).

Overall, the consolidated report on three years of Permanent Manurial Experiment revealed that favourable influence of organics, inorganics and bio-fertilizers under integrated nutrient management would have resulted in greater results on plant growth, yield parameters, tuber yield and starch content besides improved soil nutrient availability. As farmers continue to achieve higher and higher yields per unit of land ploughed, it is binding upon them to leave the land more fertile and productive than they inherited it, so that future generations can be fed without problem. Long-term adoption of INM resulted into variable functional diversity in soils. Enhanced soil microbial activity, being an agent of biochemical processes, affects nutrient dynamics and overall productive capacity of soils. This study also demonstrated that manures and fertilizers applied in the long-term could greatly affect 
biological properties, which are considered sensitive indicators of ecosystem responses and soil health.

Therefore, adoption of integrated plant nutrient supply and management strategies for enhancing soil quality, input use efficiency and crop productivity is extremely important for food and nutritional security in Indian agriculture.

\section{References}

Bharadwaj, V. and Omanwar, P. K. 1992. Impact of long term fertility treatments on bulk density, water contents and microbial population of soil. Journal of the Indian Society of Soil Science 40,pp: 553-555.

Chan, S. K. 1980. Long-term fertility considerations in cassava production. In: E. J. Weber, J. C. Toro and M. Graham (Eds.). Workshop on Cassava Cultural Practices, held in Salvador, Bahia, Brazil. March 18-21, 1980. IDRC-151 e. pp. 82-92.

Dawe, D., Doberman, A., Moya, P., Abdulrachma, S., Singh, Bijay, Lal, P.L., Lin, B., Panaullah, G., Sairam, O, Singh, Y., Swarup, A, Tan, P.S. and Zhen, Q.X. 2000. How widespread are yield declines in long term experiments in Asia. Field Crops Research 66, 175193.

Dhingra, D. A. and Sinclair, J. B. 1993. Basic Plant Pathology Methods, CBS, Pub., Delhi. pp: 179-180.

George, J., Mohankumar, C. R., Nair, G. M. and Ravindran, C. S. 2001. Cassava agronomy research and adoption of improved practices in India - Major achievements during the past 30 years. In: R. H. Howeler and S. L. Tan (Eds.). Cassava's potential in Asia in the $21^{\text {st }}$ century: Present situation and Future research and development Needs. $6^{\text {th }}$
Regional Workshop, held in Ho Chi Minh city, Vietnam, Feb 21-25, 2001.

Gupta, R.P. and Dakshinamoorthy, 1981. Procedure for physical analysis of soil and collection of agrometerological data. Division of Agrl. Physics, IARI, New Delhi.

Hagens, P. and Sittibusaya, C. 1990. Short and long term aspects of fertilizer applications on cassava in Thailand. In: R. H. Howeler (Ed.). Proc. $8^{\text {th }}$ Symp. Intern. Soc. Trop. Root Crops, held in Bangkok, Thailand, Oct 30-Nov 5, 1988. pp. 244-259.

Howeler, R. H. 1991. Long-term effect of cassava cultivation on soil productivity. Field crops Research, 26: 1-18.

Jackson, M.L. 1973. Soil chemical analysis. Oxford IBH Publishing Co., Mumbai.

Kabeerathumma, S., Mohankumar, B. Mohankumar, C. R., Nair, G. M., Prabhakar, M. and Pillai, N. G. 1990. Long range effect of continuous cropping and manuring on cassava production and fertility status of soil. In: R. H. Howeler (Ed.). Proc. $8^{\text {th }}$ Symp. Intern. Soc. Trop. Root Crops, held in Bangkok, Thailand, Oct 30-Nov 5, 1988. pp. 259-269.

Lin, X. G., Yin, R., Zhang. H. Y., Huang, J. F., Chen, R. R. and Cao, Z. H. 2004. Changes of soil microbiological properties caused by land use changing from rice-wheat rotation to vegetable cultivation.

Environmental Geochemistry and Health26: 119-128.

Malewar, G. U., Hasnabade, A. R. and Ismail, S. 1999. $\mathrm{CO}_{2}$ evolution and microbial population in soil as influenced by organic and NPK fertilizers under sorghum-wheat system. Journal of Maharashtra Agriculture University 24. pp: 121-124.

Mali, D. V., Kharche, V. K., Jadhao, S. D., Jadhao, S. M., Saoji, B. V., Gite, P. A. and Age, A. B. 2015. Soil biological 
health under Long-term Fertilization in Sorghum-Wheat sequence on swellshrink soils of Central India. Journal Indian Society of Soil Science 63 (4): 423-428.

Olsen, S.R., Cole, C.V., Watanabe, F.S. and Dean, L. 1954. Estimation of available phosphorus in soils by exractions with sodium bicarbonate. U.S.D.A. Circular No.939, U.S. Govt. Printing Office, Washington, D.C.

Piper, C.S. 1966. Soil and plant analysis. International Science Publishers, Inc., New York.

Powlson, D.S., Paul, R. and Gaunt, J.L. 1998. The role of long term experiments in agricultural development. In: LongTerm soil fertility management through Integrated Plant Nutrient Supply (A. Swarup et al., Eds). Indian Institute of Soil Science, Bhopal. pp 1-15.

Singh, A.P. 2010. Deteriorating soil health and its management for higher crop production. In: Journal of the Indian Society of Soil Science 58:41-52.

Smith, J. L. and Paul, E. A. 1990. The significance of soil microbial biomass estimations. In: Soil Biochemistry (G. Stotzky and J. M. Bollag, Eds.), Marcel Dekker, New York, pp: 357-396.

Stanford, P. and English, W.L. 1949. Use of the flame photometer in rapid soil tests of potassium and calcium. J. Environ. Qual.,21: 635-642.
Subbiah, B.V. and Asija, G.L. 1956. A rapid procedure for the estimation of available nitrogen in soils. Curr. Sci.,25: 259-260.

Susan John, K. 2005. Soil fertility evaluation of a cassava growing Typic Kandiustult of Kerala. J. Root Crops, 39 (2): 151153.

Susan John, K., Mohankumar, C. R., Ravindran, C. S. and Prabhakar, M. 1998. Long term effects of manures and fertilizers on cassava production and soil productivity in an acid Ultisol. In: Proc. National Workshop on Long germ Soil fertility management through Integrated Plant Nutrient Supply, held in IISS, Bhopal, India. Jun, 21-25, 1998. pp. 318-325.

Swarup, A 2001. Lessons from Long-Term Fertility Experiments, Indian Institute of Soil Science, Bhopal pp. 4.

Vineela, C., Wani, S. P., Srinivasarao, Ch., Padmaja, B. and Vittal, K. P. R. 2008. Microbial properties of soils as affected by cropping and nutrient management practices in several long term manurial experiments in the semi-arid tropics of India. Applied Soil Ecology, 40: 165173.

Walkley, A. and Black. C.A. 1934. An examination of the different method for determining soil organic matter and a proposed modification of the chromic acid titration method. Soil Sci.37: 29-38.

\section{How to cite this article:}

Suganya, S. 2020. Soil Biological Health, Tuber Yield and Starch Content under Permanent Manurial Experiment on Cassava. Int.J.Curr.Microbiol.App.Sci. 9(05): 2154-2162. doi: https://doi.org/10.20546/ijcmas.2020.905.246 